\title{
PENGEMBANGAN MODEL PERMAINAN TEKNIK DASAR SEPAK BOLA PADA MURID KELAS V SDNEGERI 28 KARANG PAUH KECAMATAN BAYANG KABUPATEN PESISIR SELATAN
}

\author{
Delwati $^{1}$, Sayuti Syahara ${ }^{2}$, Emral $^{3}$ \\ Fakultas IlmuKeolahragaanUniversitas Negeri Padang
}

\begin{abstract}
Abstrak: Masalah dalam penelitian ini berawal dari observasi peneliti yaitu rendahnya hasil belajar PENJASORKES murid Kelas V SD Negeri 28 Karang Pauh Kecamatan Bayang Kabupaten Pesisir Selatan. Salah satu upaya untuk meningkatkan hasil belajar PENJASORKES adalah dengan pemilihan pengembangan model permainan yang efektif dan efisien. Oleh karena itu penelitian ini bertujuan untuk melihat Pengembangan Model Permainan Teknik Dasar Sepak Bola pada Murid Kelas V SD Negeri 28 Karang Pauh Kecamatan Bayang Kabupaten Pesisir Selatan.

Jenis penelitian ini merupakan penelitian pengembangan model. Populasi pada penelitian ini adalah murid kelas V SD Negeri 28 Karang Pauh Kecamatan Bayang Kabupaten Pesisir Selatan yang berjumlah 27 orang. Setelah data didapat, maka teknik analisis data dalam penelitian ini menggunakan rumus persentase dan uji-t.

Dari Hasil penelitian ini menunjukkan bahwa Pengembangan Model Permainan dapat Meningkatkan Teknik Dasar Sepak Bola pada Murid Kelas V SD Negeri 28 Karang Pauh Kecamatan Bayang Kabupaten Pesisir Selatan terbukti dengan $t_{\text {hitung }}((115,4593)$ $>$ t table(2,0560) pada $\alpha=0.05$

Kata Kunci: Model Pemainan, TeknikDasarSepakbola
\end{abstract}

\section{PENDAHULUAN}

Pendidikan merupakan hal yang terpenting dalam kehidupan manusia , ini berarti bahwa setiap manusia berhak mendapat dan berharap untuk selalu berkembang dalam pendidikan. Pendidikan secara umum mempunyai arti suatu proses kehidupan dalam mengembangkan diri tiap individu untuk dapat hidup dan melangsungkan kehidupan. Sama halnya tujuan dari olahraga pendidikan yang dicantumkan dalam Undang-undang Republik Indonesia Nomor 3 Tahun 2005 Tentang Sistem Keolahragaan Nasional Bab I Pasal 1ayat 11 (2005:4) Olahraga Pendidikan adalah Pendidikan jasmani dan olahraga yang dilaksanakan sebagai bagian proses pendidikan yang teratur dan berkelanjutan untuk memperoleh pengetahuan, kepribadian, keterampilan,kesehatan, dan kebugaran jasmani.

Terkait dengan tujuan di atas, pendidikan jasmani merupakan bagian integral dari sistem pendidikan secara keseluruhan, bertujuan untuk mengembangkan aspek kesehatan, kebugaran jasmani, keterampilan berfikir kritis, stabilitas emosional, penalaran dan tindakan moral melalui aktivitas jasmani dan olahraga. Pendidikan jasmani mengandung makna menghasilkan peningkatan secara keseluruhan terhadap kualitas fisik, mental, dan emosional peserta didik.

Berdasarkan observasi peneliti, pada materi PENJASORKES khususnya pada kompetensi dasar permainan bola besar yaitu sepakbola, masih banyaknya 
peserta didik yang kurang sungguhsungguh dalam belajar tekhnik dasar sepakbola. Hal tersebutditunjukkan bahwa peserta didik lebih suka pembelajaran langsung kepada permainan sepakbola daripada belajar tekhnik dasar terlebih dahulu. Aktivitas pembelajaran PENJASORKES yang diberikan harus kreatif, inovatif, variatif, dan menyenangkan, sehingga tujuan pemebelajaran dapat tercapai. Salah satu cara untuk menyampaikan pengajaran tersebut adalah dengan memodifikasi sebuah pembelajaran PENJASORKES agar lebih menarik serta membuat peserta didik menjadi antusias dan aktif mengikuti pembelajaran PENJASORKES di sekolah.

Modifikasi merupakan salah satu usaha yang harus dilakukan guru untuk dapat mengembangan materi pembelajaran dalam bentuk aktivitas belajar yang potensial sehingga diharapkan dapat meningkatkan hasil belajar peserta didik. Dengan modifikasi pembelajaran dapat meningkatkan hasil belajar, minat atau partisipasi peserta didik dalam mengikuti pembelajaran dan menciptakan suasana belajar yang menyenangkan. Selanjutnya kurangnya sarana dan prasarana PENJASORKES yang terdapat di sekolah menuntut guru untuk kreatif memberdayakan dan mengoptimalkan penggunaannya.

Guru PENJASORKES cenderung menggunakan gaya mengajar tradisional dan kebanyakan guru PENJASORKES kurang kreatif dalam memberikan model pembelajaran, sehingga membuat situasi pembelajaran monotondan membosankan serta kebanyakan guru
PENJASORKES menetapkan hasil belajar tanpa memperhatikan proses pembelajaran.

Berdasarkan dari data tentang hasil belajar PENJASORKES murid Kelas V SD Negeri 28 Karang Pauh Kecamatan Bayang Kabupaten Pesisir Selatan selama 4 tahun terakhir yaitu tahun 2011 sampai 2014, yang didapatkan dari guru Kelas V SD Negeri 28 Karang Pauh Kecamatan Bayang Kabupaten Pesisir Selatan yang menyatakan bahwa hasil belajar PENJASORKES murid Kelas $\mathrm{V}$ SD Negeri 28 Karang Pauh Kecamatan Bayang Kabupaten Pesisir Selatan belum maksimal dan belum dapat dibanggakan, ini dibuktikan dari hasil belajar PENJASORKES yang telah diperoleh murid selama mengikuti proses belajar mengajar. Hasil belajar tersebut adalah rata-rata hasil belajar PENJASORKES murid berkisar 55,0060,00 . Tentu saja hasil belajar ini jauh dari hasil belajar sebelumnva atau rendah dan belum dapat dibanggakan.

Banyak faktor yang mempengaruhi hasil belajar PENJASORKES peserta didik, di antaranya adalah: (1) peserta didik itu sendiri yang kurang antusias dalam mengikuti proses pembelajaran karena pembelajaran PENJASORKES dianggap tidak bervariasi dan tidak menyenangkan; (2) guru, kurang kreatifnya guru PENJASORKES dalam membuat dan mengembangkan model pembelajaran, sehingga pembelajaran menjadi kurang menarik bagi peserta didik; (3) sarana dan prasarana yang kurang memadai, karena menurut Ateng (1992: 1) bahwa "pendidikan jasmani berkaitan dengan perasaan, hubungan 
pribadi, tingkah laku kelompok, perkembangan mental dan sosial, intelektual, serta estetika." Pendidikan jasmani meskipun berusaha untuk mendidik manusia melalui sarana jasmani, dengan aktivitas-aktivitas jasmani atau aktivitas fisik, tetap berkepentingan dengan tujuan-tujuan pendidikan yang tidak semuanya jasmani atau fisik. Menurut Alnedral (2014: 10) "Dalam Pendidikan Jasmani Olahraga dan Kesehatan pembelajaran dilakukan melalui gerak yang dapat meningkatkan kemampuan kea rah afektif (sikap), kognitif (pengetahuan) dan psikomotor (keterampilan) bagi peserta didik yang mengikuti proses pembelajaran.

Jika tujuan pembelajaran tersebut diatas dapat di tingkatkan, ini juga berarti menyangkut kepada kemampuan pendidik dalam memberikan metode serta menjalankan proses pembelajaran. Jika tujuan tersebut tidak dicapai, hal ini diduga disebabkan karena kurangnya pengembangan metode pembelajaran yang bervariasi oleh guru dan pada akhirnya peserta didik merasa kurang menguasai tekhnik dasar dan peserta didik hanya ingin langsung dalam bentuk permainan, terlihat dari nilai rata-rata hasil belajar dalam pembelajaran sepakbola pada kelas $\mathrm{V}$ tahun ajaran 2013/2014 hanya 7 anak saja dari 27 peserta didik atau hanya sebesar $25,92 \%$ yang mencapai nilai lebih dari nilai KKM (Kriterian Ketuntasan Minimal). Dalam hal ini perlua adanya pengembangan atau modifikasi dalam permainan sepakbola terutama dalam tekhnik dasar dalam permainan. Dalam menentukan strategi pembelajaran modifikasi permainan sepakbola perlu mempertimbangkan pribadi peserta didik, sarana dan prasarana dan waktu sesuai dengan karakteristik peserta.

Untuk mengatasi hal ini, maka perlu diadakan penelitian dengan pengembangan model pembelajaran PENJASORKES khususnya pada permainan bola besar yaitu sepakbola pada murid kelas $v$ SD Negeri 28 Karang Pauh Kecamatan Bayang Kabupaten Pesisir Selatan. Sangat dibutuhkan sekali kreativitas guru yang inovatif agar pembelajran menjadi menarik dan menyenangkan khususnya bagi peserta didik, karena pada usia inilah tahap persiapan atau tahap pembelajaran dasar-dasar permainan sepak bola. Hal tersebut dinyatakan oleh Sukatamsi (1997:25) "usia 7-12 tahun: tahap persiapan atau tahap permasalahan, ialah tahap belajar dasar-dasar permainan sepak bola, penguasaan teknik-teknik dasar, pengajaran permainan sepak bola". Melalui pengkajian dapat ditemukan langkah-langkah untuk memperbaikinya. Dalam inovasi pembelajaran PENJASORKES terdapat aspek yaitu; aspek kognitif, aspek afektif, aspek psikomotor. Ketiga aspek tersebut harus muncul dalam proses pembelajaranPENJASORKES sehingga tujuan pembelajaran dapat dicapai.

Proses pembelajaran akan berjalan dengan baik jika pendidika menguasai seperti apa pembelajaran yang akan ia lakukan. Hal tersebut menyangkut kepada model pembelajaran. Menurut Alnedral (2014: 76) model pembelajaran dimaksudkan sebagai suatu objek atau konsep yang 
digunakan untuk mempresentasikan sesuatu hal yang menggambarkan adanya pola berfikir. Selain daripada itu menurut Ahmadi dan Amri (2014:56)" model pembelajaran adalah suatu rencana atau pola yang dapat digunakan untuk membentuk kurikulum (rencana pembelajaran jangka panjang), merancang bahan-bahan pembelajaran, dan membimbing tindakan/alsi pengajar. Dengan adanya model pembelajaran yang telah dirancang sebelum proses pembelajaran dilaksanakan, maka proses pembelajaran akan berhasil dan pencapai tujuan dari pembelajaran akan didapat.

Adapun tujuan dari model pembelajaran yang diberikan adalah untuk mempermudah proses pembelajaran. Sesuai dengan yang disampaikan oleh Alnedral (2014: 76) "model berfungsi sebagai sarana untuk mempermudah komunikasi,atau sebagai petunjuk yang bersifat perspektif untuk mengambil keputusan, atau sebagai petunjuk perencanaan untuk kegiatan pengelolaan. Selain dari itu menurut Joyce dkk dalam Ahmadi dan Amri (2014:56) model pembelajaran adalah deskripsi suatu lingkungan pembelajaran yang disusun berdasarkan tujuan yang ingin dicapai, pembelajaran di kelas, kelompok belajar, dan latihan-latihan untuk mendesain instruksional berbagai materi pelajaran, program multi media, serta program-program pembelajaran melalui komputer.

Pembuatanmodel-model

$\begin{array}{lcr}\text { pembelajaran } & \text { akan } & \text { kreativitas } \\ \text { pembelajaran } & \text { dalam } & \text { rangka } \\ \text { memunculkan } & \text { motivasi } & \text { dan } \\ \text { meningkatkan } & \text { kemampuan } & \text { murid }\end{array}$

merupakan salahsatu bentuk tujuan dilakukannya modifikasi pembelajaran oleh guru. Modifikasi menurut kamus besar bahasa Indonesia adalah pengubahan : perubahan rencana dari bentuk semula. Modifikasi merupakan salah usaha yang dapat dilakukan oleh guru agar pembelajaran mencerminkan Developmentally Appropriate Practice (DAP). Oleh karena itu, DAP termasuk didalamnya "Body scaling" atau ukuran tubuh murid, harus selalu dijadikan prinsip utama, dalam memodifikasi pembelajaran Pendidikan jasmai olahraga, dan kesehatan. Esensi modifikasi adalah menganalisa sekaligus mengembangkan materi pelajaran dengan cara, merumuskannya dalam bentuk aktivitas belajar yang potensial sehingga dapat memperlancar murid dalambelajar. Cara ini dimaksudkan untuk menuntun, mengarahkan, dan membelajarkanmurid dari yang tadinya tidak bisa menjadi bisa, dari tingkat yang rendah ke tingkat yang lebih tinggi. Jadi modifikasi adalah suatu cara atau usaha yang dilakukan guru berupa rancangan model pembelajaran yang baru dan lebih variatif untuk menarik minat murid agar lebih aktif dalam mengikuti pembelajaran dan dapat menciptakan perubahan, sekaligus meningkatkan mutu pendidikan.

Pendidikan jasmani adalah pendidikan melaluiaktivitasjasmani. Pendidikan jasmani tidak lepas dari usaha pendidikan pada umumnya. Menurut Sukintaka (2001:17) pendidikan jasmani merupakan bagian integral dari pendidikan total yang mencoba mencapai tujuan untuk mengembangkan kebugaran jasmani, mental, sosial, serta 
emosional bagi masyarakat, dengan wahana aktivitas jasmani. Ini jelas bahwa pendidikan jasmani merupakan bagian integral pendidikan keseluruhan yang mampu mengembangkan anak/individu secara utuh dalam arti mencakup aspek-aspek jasmaniah, intelektual, emosional dan moral spiritual yang dalam proses pembelajarannya mengutamakan aktivitas jasmani dan pembiasaan pola hidup sehat.

Sehubungan dengan ungkapan di atas BNSP (2006:648) mendefinisikan bahwa pendidikan jasmani merupakan bagian integral dari pendidikan secara keseluruhan. Pendidikanjasmani adalah pendidikan melaluiaktivitas gerak dan pelaksanaan pendidikan jasmani harus diarahkan pada pencapaian tujuan pendidikan. Tujuan pendidikan jasmani bukan aktivitas jasmani, tetapi untuk mengembangkan potensi murid melalui aktivitas

jasmani

peluanguntukmengembangkansemuaas

pek, pribadimanusia, tanpamengabaikan norma-norma pendidikan.

Pendidikan jasmani Olahraga dan Kesehatan (PENJASORKES) merupakan bagian integral dari pendidikan secara keseluruhan, bertujuan untuk mengembangkan aspek kebugaran jasmani, keterampilan gerak, keterampilan berfikir kritis, keterampilan sosial, penalaran, stabilitas emosional, tindakan moral, aspek pola hidup sehat, dan pengenalan lingkungan bersih melalui aktivitas jasmani, olahraga dan kesehatan terpilih yang direncanakan secara sistematis dalam rangka mencapai tujuan pendidikan nasional. Menurut Alnedral (2014: 10) "Dalam Pendidikan Jasmani Olahraga dan
Kesehatan pembelajaran dilakukan melalui gerak yang dapat meningkatkan kemampuan kearah afektif (sikap), kognitif (pengetahuan) dan psikomotor (keterampilan) bagi peserta didik yang mengikuti proses pembelajaran".

Sepakbola merupakan salah satu olahraga permainan bola besar. Menurut Sukatamsi (1997: 3) Sepakbola adalah permainan dimainkan oleh dua regu yang masing-masing regu terdiri atas 11 orang. Permainan sepakbola bertujuan untuk memasukkan bola ke gawang lawan. Regu yang lebih banyak memasukkan bola ke gawang lawan menjadi pemenangnya. Permainan Sepakbola diperkenalkan pada anak usia sekolah dasar, dan dimasukkan ke dalam kurikulum pembelajaran.

Pada dasarnya permainan sepakbola merupakan suatu usaha untuk menguasai bola dan untuk merebutnya kembali bila sedang dikuasai oleh lawan. Oleh karena itu, untuk dapat bermain sepakbola harus menguasai teknik-teknik dasar sepakbola yang baik. Untuk dapat manghasilkan permainan sepakbola yang optimal, maka seorang pemain harus dapat menguasai teknik-teknik dalam permainan. Menurut Sukatamsi (1997:2.2) "Teknik dasar bermain sepakbola adalah semua gerakangerakan tanpa bola dan gerakangerakan dengan bola yang diperlukan untuk bermain sepak bola. Jadi teknik dasar bermain sepak bola adalah merupakan kemampuan untuk melakukan gerakan-gerakan atau mengerjakan sesuatu terlepas sama sekali dari permainan sepak bola." 
Menyangkut dengan hal tersebut di atas, sepakbola merupakan salah satu olahraga permainan bola besar. Menurut Sukatamsi (1997: 3) Sepakbola adalah permainan dimainkan oleh dua regu yang masing-masing regu terdiri atas 11 orang. Permainan sepakbola bertujuan untuk memasukkan bola ke gawang lawan. Regu yang lebih banyak memasukkan bola ke gawang lawan menjadi pemenangnya. Permainan Sepakbola diperkenalkan pada anak usia sekolah dasar, dan dimasukkan ke dalam kurikulum pembelajaran.

\section{METODE}

Jenis penelitian yaitu penelitian pengembangan model maka tujuan penelitian ini adalah menghasilkan model permainan yang digunakan pembelajaran materi sepakbola pada kelas V SD Negeri 28 Karang Pauh Kecamatan Bayang Kabupaten Pesisir Selatan. Penelitian ini dilaksanakan pada semester II tahun pelajaran 2014/2015, yaitu dari tanggal 18 februari sampai dengan 18 april 2015. Dengan materi permainan sepakbola.

\section{HASILDAN PEMBAHASAN}

Dari analisis yang dilakukan, nilai $t$ hitungantara tes awal dan tes akhir pengembangan model permainan dalam meningkatkan teknik dasar sepak bolasiswa menunjukkan angka sebesar 115,4593 selanjutnya nilai yang diperoleh dibandingkan dengan $\mathrm{t}$ table pada taraf signifikan 0,05 dengan derajat kebebasan $\mathrm{N}-1$ (26) ternyata nilai yang diperoleh adalah 2,0560 hal ini menunjukkan bahwa nilai $t$ hitung $(115,4593)>\mathrm{t}$ table $(2,0560)$ dengan demikian dapat disimpulkan bahwa terdapat pengembangan model permainan teknik dasar sepak bola pada murid kelas V SD Negeri 28 Karang Pauh Kecamatan Bayang Kabupaten Pesisir Selatan.

Proses pembelajaran akan berjalan dengan baik jika pendidikan menguasai seperti apa pembelajaran yang akan ia lakukan. Hal tersebut menyangkut kepada model pembelajaran. Menurut Alnedral (2014: 76) model pembelajaran dimaksudkan sebagai suatu objek atau konsep yang digunakan untuk mempresentasikan sesuatu hal yang menggambarkan adanya pola berfikir. Selain daripada itu menurut Ahmadi dan Amri (2014:56)" model pembelajaran adalah suatu rencana atau pola yang dapat digunakan untuk membentuk kurikulum (rencana pembelajaran jangka panjang), merancang bahan-bahan pembelajaran, dan membimbing tindakan/aksi pengajar. Dengan adanya model pembelajaran yang telah dirancang sebelum proses pembelajaran dilaksanakan, maka proses pembelajaran akan berhasil dan pencapai tujuan dari pembelajaran akan didapat.

Adapun tujuan dari model pembelajaran yang diberikan adalah untuk mempermudah proses pembelajaran. Sesuai dengan yang disampaikan oleh Alnedral (2014: 76) “ model berfungsi sebagai sarana untuk mempermudah komunikasi,atau sebagai petunjuk yang bersifat perspektif untuk mengambil keputusan, atau sebagai petunjuk perencanaan untuk kegiatan pengelolaan. 
Dengandihasilkannyamodel-model akanmenghasilkanindekspembelajaran maka akan adanya kreativitas, pembelajaran

melaluikreativitasdiharapkanakanmemun culkanmotivasidanmeningkatkankemam puan murid. Inimerupakanperwujudanmengapasemu aharusmelaluikreatifdanmelakukanberba gaimacammodifikasidalampembelajaran nya.

Modifikasi merupakan salah usaha yang dapat dilakukan oleh guru agar pembelajaranharusmenyatukepadakons epDevelopmentally Appropriate Practice (DAP). DAP termasuk didalamnya "Body Scaling" atau ukuran tubuh murid, harus selalu dijadikan prinsip utama, dalam memodifikasi pembelajaran Pendidikan jasmani olahraga, dan kesehatan. Esensi modifikasi adalah menganalisa sekaligus mengembangkan materi pelajaran dengan cara, merumuskannya dalam bentuk aktivitas belajar yang potensial sehingga dapat memperlancar murid dalambelajar.

Cara ini dimaksudkan untuk menuntun, mengarahkan, dan membelajarkan murid dari yang tadinya tidak bisa menjadi bisa, dari tingkat yang rendah ke tingkat yang lebih tinggi. Jadi modifikasi adalah suatu cara atau usaha yang dilakukan guru berupa rancangan model pembelajaran yang baru dan lebih variatif untuk menarik minat murid agar lebih aktif dalam mengikuti pembelajaran dan dapat menciptakan perubahan, sekaligus meningkatkan mutu pendidikan.

Pendidikan jasmani tidak lepas dari usaha pendidikan pada umumnya. Menurut Sukintaka (2001:17) pendidikan jasmani merupakan bagian integral dari pendidikan total yang mencoba mencapai tujuan untuk mengembangkan kebugaran jasmani, mental, sosial, serta emosional bagi masyarakat, dengan wahana aktivitas jasmani. Ini jelas bahwa pendidikan jasmani merupakan bagian integral pendidikan keseluruhan yang mampu mengembangkan anak/individu secara utuh dalam arti mencakup aspek-aspek jasmaniah, intelektual, emosional dan moral spiritual yang dalam proses pembelajarannya mengutamakan aktivitas jasmani dan pembiasaan pola hidup sehat.

Kurikulum

pembelajaran mengajarkanteknik-teknik dasar sepakbola. Teknik-teknik dasarnya adalah teknik dasar menendang bola, teknik dasar mengontrol bola, menggiring bola, menyundul bola. Keempat teknik dasar tersebut sudah diberikan pada anak usia sekolah dasar kelas $\mathrm{V}$. hal tersebut menyangkut tentang karakter anak yang telah duduk pada kelas $\mathrm{V}$ sekolah dasar.

Nilai akhir teknik dasar sepak bola murid sebelum dilakukan pengembangan model permainan, jika dibandingkan dengan kategori nilai psikomotorik maka dapat ditentukan bahwa dari 27 orang murid, sebanyak 13 orang murid memiliki nilai akhir teknik dasar sepak bola pada kategori baik dan 14 orang orang murid memiliki nilai akhir teknik dasar sepak bola pada kategori cukup. Sedangkan untuk kategori baik sekali, kurang dan sangat kurang tidak ada. Nilai akhir murid yang paling rendah adalah 50.00 dan nilai akhir murid yang paling tinggi adalah 66.67. Sedangkan bila dibandingkan dengan 
kategori nilai teknik dasar maka dapat ditentukan bahwa dari 27 orang murid, sebanyak 11 orang murid dinyatakan telah lulus dan 16 orang murid dinyatakan tidak lulus.

Kemudian nilai akhir teknik dasar sepak bola murid sesudah pengembangan model permainan, jika dibandingkan dengan kategori nilai psikomotorik maka dapat ditentukan bahwa dari 27 orang murid, sebanyak 5 orang murid memiliki nilai akhir teknik dasar sepak bola pada kategori baik sekali dan sebanyak 22 orang murid memiliki nilai akhir teknik dasar sepak bola pada kategori baik. Sedangkan untuk kategori cukup, kurang dan sangat kurang tidak ada. Nilai akhir murid yang paling rendah adalah 66.67 dan nilai akhir murid yang paling tinggi adalah 83.33. Sedangkan bila dibandingkan dengan kategori nilai teknik dasar maka dapat ditentukan bahwa dari 27 orang murid, sebanyak 27 orang murid dinyatakan telah lulus dan murid yang dinyatakan tidak lulus tidak ada.

Berdasarkanhasil di atas jelas bahwa perbedaaan kedua nilai akhir teknik dasar sepak bola sebelum dan sesudah pengembangan model permainan. Nilai akhir teknik dasar sepak bola sesudah diberikan pengembangan model permainan nampak jelas peningkatan, walau peningkatannya sedikit. Ini dapat dilihat dari selisih antara rata - rata setelah pengembangan model permainan dengan rata-rata sebelum pengembangan model permainan adalah 16.46.

\section{KESIMPULAN}

Berdasarkan hasil penelitian di atas maka dapat di ambil kesimpulan bahwa, Rancangan Pengembangan Model Permainan Teknik Dasar Sepak Bola pada Murid Kelas V SD Negeri 28 Karang Pauh Kecamatan Bayang Kabupaten Pesisir Selatan

Untukmeningkatkankemampuanbe rmainsepakbola, dimanamodel-model tersebutadalahUlar Melingkar, Permainan Bola Gila, Terobos Lorong, Si Buta, Bidik Kolong, Tembak Pohon Kelapa, Bowling, Berburu Kelinci, Bulan Sabit, Permainan Lingkaran Kotak, Gawang Berjalan, Sentuh Tubuh, Kucing-kucingan, Segitiga, Takraw Kurakura, danTakraw Sundul.

\section{DAFTAR RUJUKAN}

Adang Suherman. 2000. Dasar-dasar Penjaskes. Jakarta : Depdikbud.

Adang Suherman dan Yoyo Bahagia. 2000. Prinsip-prinsip

Pengembangan dan Modifikasi Cabang Olahraga. Jakarta : Depdikbud.

Ahmadi, lif Khoiru \& Sofan Amri. 2014. Pengembangan dan Model Pembelajaran Tematik integrative. Jakarta : Prestasi Pustaka

Alnedral. 2014. Strategi Pembelajaran PJOK. Padang: FIK-UNP.

BSNP. 2006. Panduan Penyusunan KTSP Jenjang Pendidikan Dasar dan Menengah. Jakarta: Depdiknas

Callery, Sean. 1991. Soccer Technique, TacTics, Training. Hongkong : The Crowood Press Ltd Gifford, Clive. 2007. Keterampilan Sepak Bola. Yogyakarta: Intan Sejati. 
(terjemahan oleh Andi $\begin{array}{r}\text { Luxbacher, Joseph A. 2001. Sepakbola. } \\ \text { Setyawan) }\end{array}$
Jakarta : PT. Raja Grafindo.

Huizinga, J. (1990). Homo ludens Mielke, Danny. 2003. Soccer (terjemahan). Jakarta: LP3ES.

Kamus Besar Bahasa Indonesia. 2005.

Departemen Pendidikan

Nasional: Balai Pustaka.

Kemenegpora. (2005). Undang -

Undang Republik Indonesia

Nomor 3 Tahun 2005 Tentang

Sistem Keolahragaan Nasional. Jakarta : Kemenegpora RI

Koger, Robert. 2005. Latihan Dasar

Andal Sepakbola Remaja . Us : McGraw-Hill
Fundamentals. United States :

Kinetics Publishers.

Putra, Yulio Mariem. 2013.

Pembelajaran Gerak Dasar Sepakbola dengan Pendekatan Bermain. Tesis tidak diterbitkan. Jakarta: UNJ.

Ma'u, Mellius dan J. Santoso. 2014. Teknik Dasar Bermain Sepak Bola. Yogyakarta: Cakrawala.

Tentang Sistem Keolahragaan Nasional 